\title{
Analysis on Rock Art in Qarasu River Basin at Meshgin Shahr (Azerbaijan)
}

\author{
Mohammad Mirzaei ${ }^{1}$, Najmeh Nouri ${ }^{2, ~ *}$, Ali Karimi Kiya ${ }^{3}$, Nasrin Alizadeh ${ }^{4}$ \\ ${ }^{1}$ Faculty of Literature and Humanities, Archaeology in University Sistan \& Baluchistan, Zahedan, Iran \\ ${ }^{2}$ Faculty of Preservation and Restoration, Archaeology in Isfahan University of Art, Isfahan, Iran \\ ${ }^{3}$ Faculty of Literature and Humanities, Archaeology in University Tehran, Tehran, Iran \\ ${ }^{4}$ Faculty of Art, Art research in Islamic Azad University of Ramsar, Ramsar, Iran \\ Email address: \\ noori_najmeh@yahoo.com (N. Nouri) \\ ${ }^{*}$ Corresponding author
}

\section{To cite this article:}

Mohammad Mirzaei, Najmeh Nouri, Ali Karimi Kiya, Nasrin Alizadeh. Analysis on Rock Art in Qarasu River Basin at Meshgin Shahr (Azerbaijan). International Journal of Archaeology. Vol. 4, No. 5, 2016, pp. 54-60. doi: 10.11648/j.ija.20160405.11

Received: July 12, 2016; Accepted: July 20, 2016; Published: August 3, 2016

\begin{abstract}
The rock art can be seen in Iran in most of mountainous regions where roaming life and livestock- farming are prevalent typically. The studied site in Qarasu River basin- locating in Meshgin Shahr city- has clarified dark and ambiguous views of this new tendency at North West region of Iran. This art has been implemented by various techniques on surfaces of various rocks and stones since ancient time that may typically strike in mind the life of creators, their relationship with adjacent lands, and ideology and intellectual and aesthetic excellence of different human communities over long years. One can find the evidences about lifestyle of primitive inhabitants in this area and their art and other ambiguous cultural points of them by study on these artifacts. The important areas such as Pirazmiyan, Nuqdu, Chapaqan, Dedebeyglu, Shikh Medi, and Deve Deresi regions include valuable Rock Art in Qarasu River basin and due to their similarities they have been probably related to each other. Survey has been done on Rock Art designs in the studied region according to field studies and the existing designs have been classified into three groups of human, animal, and rock-pit and introduced as geometric- symbolic designs where they have been investigated regarding this point that what kind of relationship and continuities might exist among living and environmental backgrounds with this region.
\end{abstract}

Keywords: Azerbaijan, Meshgin Shahr, Qarasu River, Rock Art

\section{Introduction}

The conducted studies on rock arts may represent position of these artifacts in recognition of cultural history of a certain land (range of stylistics and social beliefs and structures). Study and survey on rock manuscript in all continents was started at wide range and it has been converted into one of the most modern and interesting study works for anthropologists, archeologists, ecologists, and researchers of decorative arts [14]. The Rock Art designs are considered as inseparable and integrated part of human history that has been effective in trend of growth and intellectual and aesthetic excellence of various human communities [21]. While from archeological perspective, quality of relationship among this sector with monuments and adjacent ancient habitats has not been studied widely at least in Iran. Overall, Rock Art is classified into four groups including petroglyph, pictoglyph, rock-pit or cup-like designs, and geoglyph [20]. Researchers of historic arts consider Rock Art as the foremost and most mysterious types of archeological and historical artifacts so that one can refer to human's common language and live archive of history to understand human history [16].

The abundance of rock arts in North West of Iran has attracted a lot of attention. Some of the studies on the rock art of this region are as follows: Arasbaran petroglyphs (Sungun) $[17,18]$, Arasbaran rock art [19], petroglyphs art on North West of Iran [17], Shahar Yeri rock arts [7], Arasbaran petroglyphs [9], Archeological surveys on Deve Dashi in Zanjan [15] and studying Iran North West petroglyphs 
especially Duzdaqi rock reliefs on North West of Iran [11]

\section{Methodology}

The researches have been conducted on rock Art in Qarasu River basin at Meshgin Shahr based on field studies and by virtue of librarian sources. The goal of current research is to introduce perfectly this site in a monograph where in this study we will introduce each of them. Depth and difference in color and way of erosion of designs as well as comparison of them with adjacent designs, especially Qobustan region, are deemed as some factors that can be considered in calendar and order- preferences of their formation. With respect to the existing evidences and proofs, one can attribute these paintings to prehistoric and historic periods when creation of these paintings has been also continued in subsequent eras. The lateral valleys of Qarasu River with natural rocks have been always deemed as best place for creation of these paintings. The regional inhabitants have drawn these images by their specific skills from this complex to Nuqdu, Chapaqan, Dash, Dedebeyglu valley, Shikh Medi, and to Mashiran etc passing through the abundant river where the effect of Qarasu River is crucially important in formation of settlements and generation of rock arts. (Fig. 1) Qarasu River water basin is one of main branches of Aras River. The surface area of Qarasu River is over $14^{\prime} 310 \mathrm{~km}^{2}$ and it is assumed as one of the important water basins in this region in terms of climatic potential. (Fig. 2)

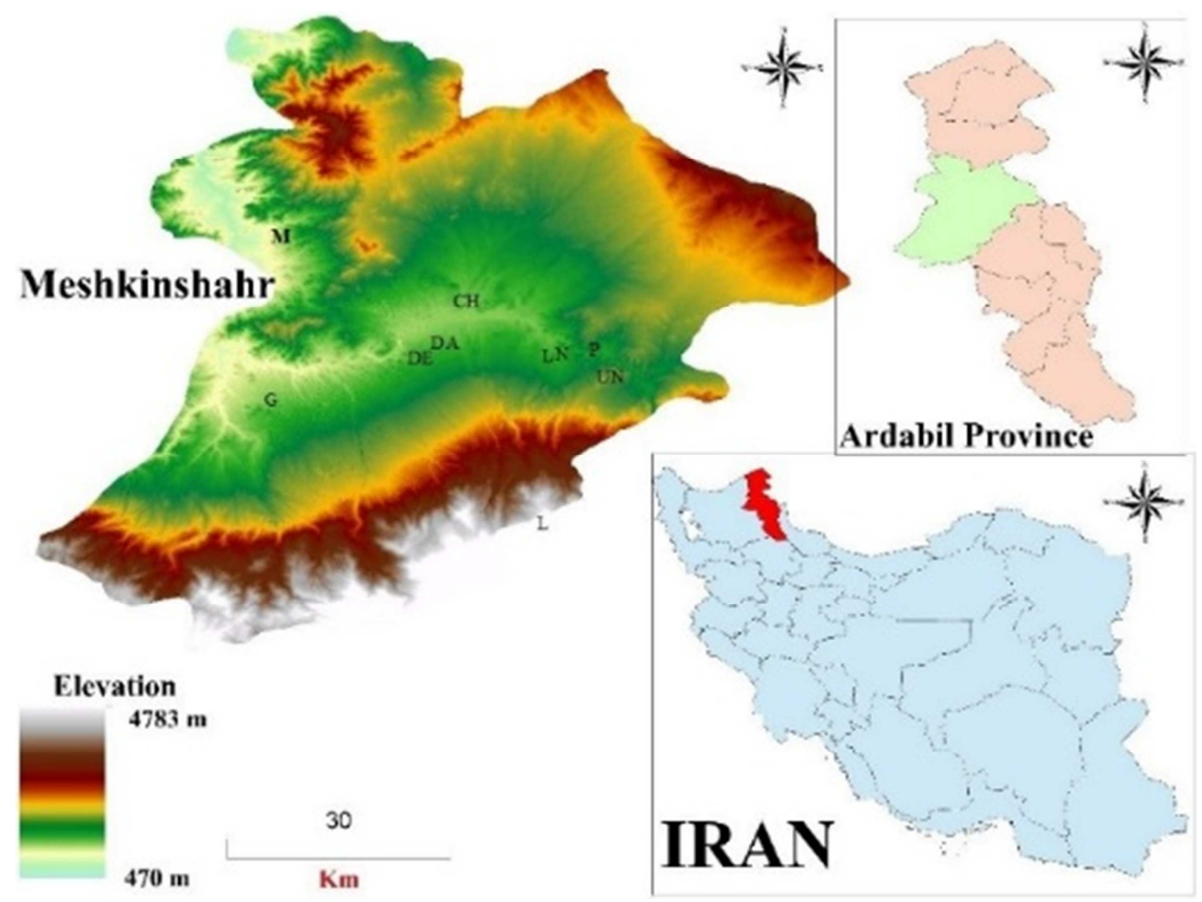

Fig. 1. Position of sites on map: Pirazmiyan: UN: Upper Nuqdu; UL: Lower Nuqdu; CH: Chapaqan; DA: Dash; DE: Dedebeyglu valley; and G: Giller Mohammad Hassan.

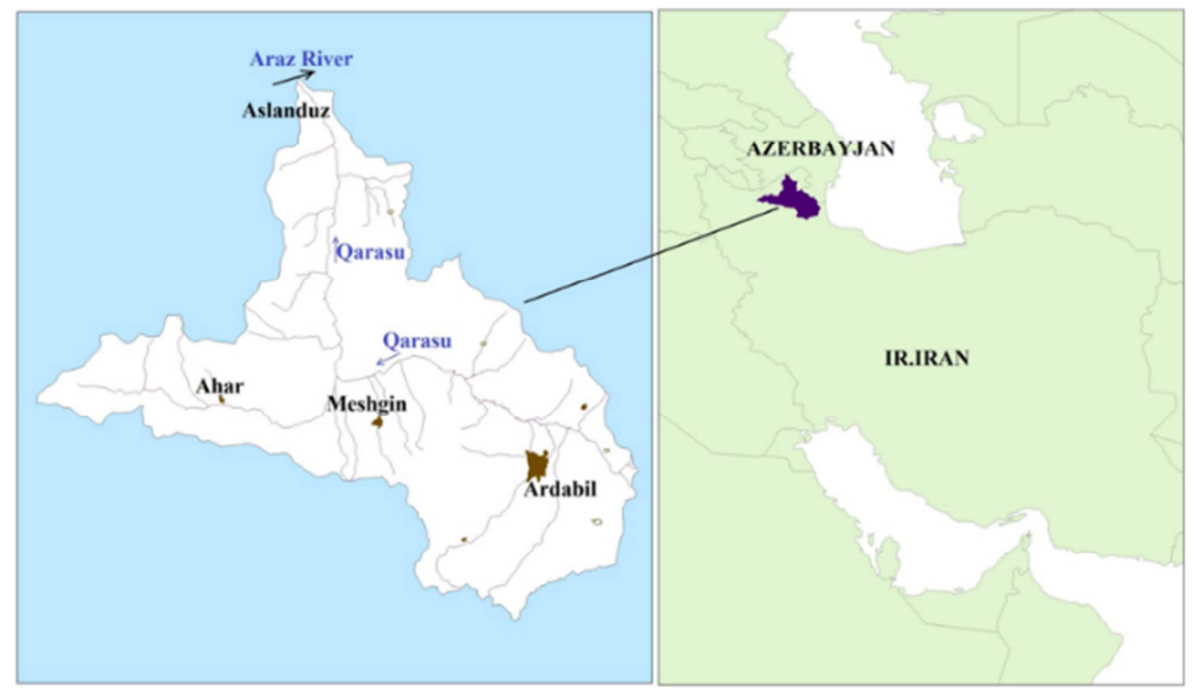

Fig. 2. Position of Qarasu River water basin. 


\section{Pirazmiyan Designs}

Pirazmiyan site is situated at $40 \mathrm{~km}$ distance from northeast of Meshgin Shahr on $110 \mathrm{~m}$ higher than sea level and respectively in geographic latitude and longitude $\left(38^{\circ}, 32^{\prime}\right.$, $\left.42^{\prime \prime}\right)$ and $\left(47^{\circ}, 38^{\prime}, 15^{\prime \prime}\right)$ and at western side of Sabalan Dam. The given site has been drawn in two separate parts from each other.

This area has been studied in two different sites by authors in 2014. One part is located at eastern side of entry at the mouth of Sabalan Dam that is called eastern site and the other unit that enjoys more various in terms of subject and it is called western site at the west of this region. In units of eastern sites only design of antelope was drawn but various subjects of social life of humans have been implemented in this region. There are 19 goat paintings in eastern unit. Most of painting designs are located at western side of mouth of Sabalan Dam including 8 tableaus with animal designs (picture of horned goats in special forms). Unlike other units in this region, all of painting designs have been inscribed by abrasive technique. Designs that have been drawn by shepherds during recent decades are abrasive. Also, today these shepherds are visible along with long-horn goats beside this archeological site. Many shepherds are inhabitants of Lower Nuqdu village and Pirazmiyan region. The wellknown region of Yeri city is located $3 \mathrm{~km}$ distant from these painting designs where their dates have been marked by excavators from Neolithic era to Iron Age.

A group of the given rock arts in Iran and Azerbaijan (Gemi qaya designs) include design of flocks of goats, which move in certain directions. The pictures of animals have been drawn while they stand in pairs in two opposite directions and with composition of two animals e.g. goat and goat and sometimes goat and deer [3]. These pictures are similar to animal designs on cultural artifacts in Xocali Gedebey at south Caucasia in terms of form [23]. In both regions, most of rock arts are related to religious beliefs and ideology of animal husbandry- farmer tribes and generally indicate scenes of their sustenance and economic life and some of them follow realistic styles [2].

Western site is located at the west of Sabalan Dam. Overall, 10 goat designs have been drawn in this area. One of the most original subjects in this unit is moving human design and symbolic geometric designs. Also some similar paintings with the same design have been drawn in Mashiran site- at the end of Qarasu River basin within limit of Meshgin Shahr [10].

Human design has been exclusive seen in Pirazmiyan and Dash sites during archeological investigation in 2014. Designs of three humans are of abrasive type in Pirazmiyan site but colorful design technique has been utilized in Dash site (Fig. 3). The similar designs have been also inscribed in Shikh Medi site with variable sizes of rocks at different levels. The rock art has been found as pictograph (colorful design) in some areas e.g. Kuhdasht at Lorestan (Dusheh and Mir Malas caves and Hamyan designs site) [8]; Eshkaft Bastak at Hormozgan [18], and at North Khorasan in mountainous region and south Farooj near to Bash Mahaleh, Zinekanloo, and Upper Nargesloo villages at west Bojnurd.

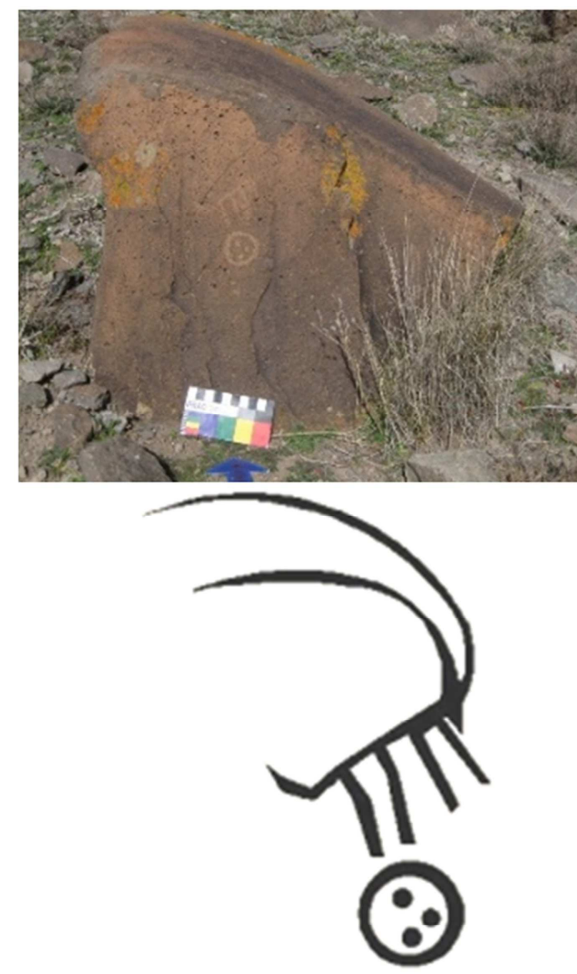

Pirzamiyan site

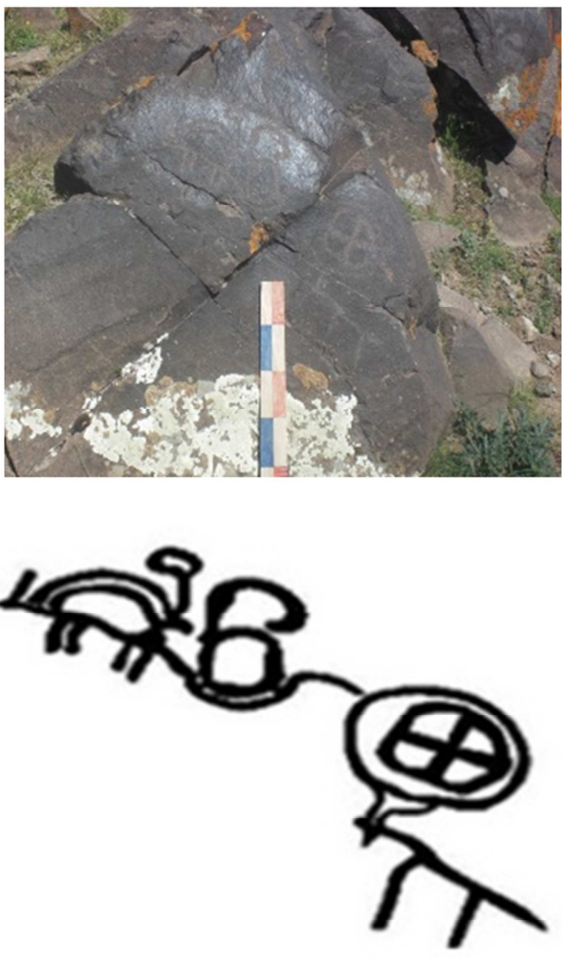

Mashiran site [10]
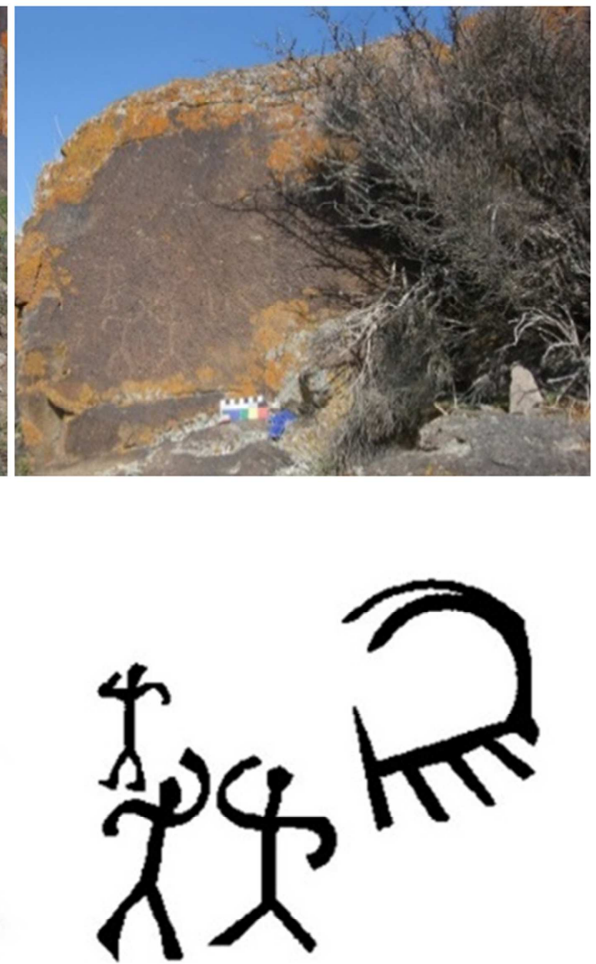

Pirzamiyan site

Fig. 3. Designs animal, human and symbolic in Pirazmiyan (Authors). 
Designs of dancing humans are visible in all of these sites and there is only difference in dancing group or individuals. This group of paintings with (dancing) human designs in Qobustan that is located at the nearest position to our discussed site i.e. Qarasu includes many similarities. This group has been examined by laboratory samples (estimation date of designs) therefore it is better to compare designs of these two sites with each other. There are collective paintings among rock arts at Qobustan region, but Rock Art designs in Qarasu site are under inappropriate apparent conditions compared to Qobustan and they have been worked very primitively in terms of artistic technique as well. These landscapes denote happiness scenes (e.g. successful hunting and wedding etc.) and or type of symbolic dance. There is a stony manger beside this site that has been built by shepherds for their livestock. Title of 'Ali' has been inscribed by abrasive technique at higher point than other designs during recent decades. Presence of title of 'Mohammad' in Dash site and title of 'Ali' in Pirazmiyan indicates religious beliefs of present inhabitants of this region in social dimension. The other point is that picture of goats has been drawn by sharp tip line and in some cases without head. This animal is one of group of animals that were living collectively since long time ago in Iranian plateau and abundantly in various regions within different geographic regions in various races such as Alborz, Ural, Cooper, and Larestan and today despite of inadvertent hunting, there are still some groups of Bovidae that are visible in different mountainous regions in particular.

\section{Nuqdu Site}

This site has been drawn at $25 \mathrm{~km}$ distant from east of Meshgin Shahr and $3 \mathrm{~km}$ from ancient Pirazmiyan region. Goat design has been inscribed by abrasive technique in Upper Nuqdu and at the eastern margin of Ardebil- Moghan Road on a conical rock.

Similarly, a Rock Art site is placed at the center of Lower Nuqdu village respectively at geographic latitude and longitude $\left(38^{\circ}, 32^{\prime}, 00^{\prime \prime}\right)$ and $\left(47^{\circ}, 56^{\prime}, 48^{\prime \prime}\right)$ at point $1100 \mathrm{~m}$ higher than sea level where only one goat design is seen on the surface of these rocks.

\section{Dedebeyglu Site}

Another site was found during investigation in 2014 where given design has been drawn by present inhabitants in recent years. These painting designs are visible at north side of village and located at geographic latitude and longitude $\left(38^{\circ}\right.$, 33', 45") and (47, 51', 07") and beside Qarasu River. Approximately equilateral triangular design is seen in this site where two quadrangles are visible at eastern side, two quadrangles at north, three quadrangles at west, and also two quadrangles at the south. Plus sign with $8 \mathrm{~cm}$ length is placed in both of them at the other side and it is written R3 on piece of rock at the west side. These designs have been surely engraved during recent decades.

\section{Chapaqan Site}

The similarity of this site with Pirazmiyan site is related to arrangement and design of subjects in both sides of Qarasu River where one of them is located at north direction (Suvama dashi). One of the best designs in this ancient site is a group of small Cupule pits at the northern part of Qartal (Eagle's Body) at Chapaqan area. The Cupules rock pit designs are also placed in Dash site and this type of paintings has been created at different depths. This type of rock-pits has been also found in Ancient site of Qobustan at Azerbaijan Republic in addition to Iran and other point of this country. The Cupule (sequin-like) designs may be considered for counting function or a type of game. (Fig. 4)

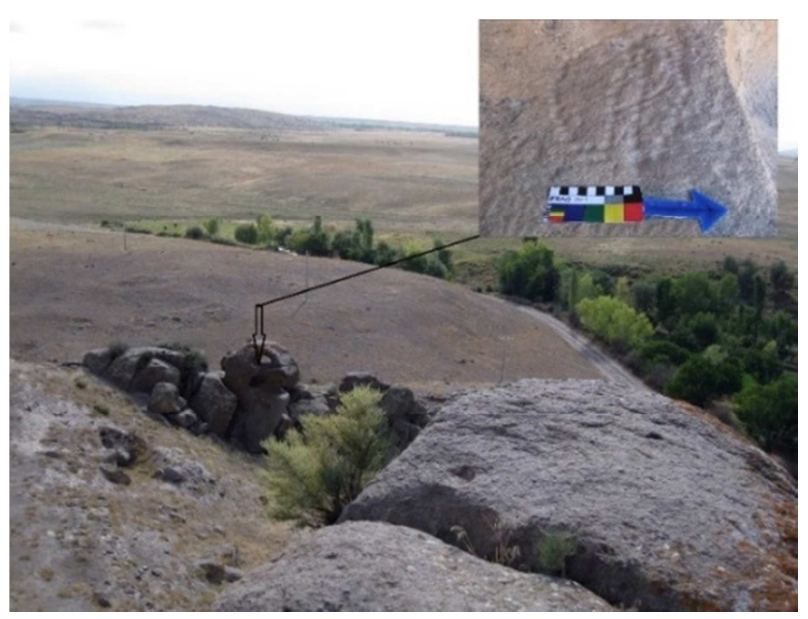

Fig. 4. Especial Cupules in Chapaqan complex [13].

Among mass of these paintings, deer design with long horns has been drawn realistically. One of the foremost achievements in study of Chapaqan site at north area (Suvama dashi) is to find two pieces of a hand axe that has been made by Levalloisian technique (Fig. 5)
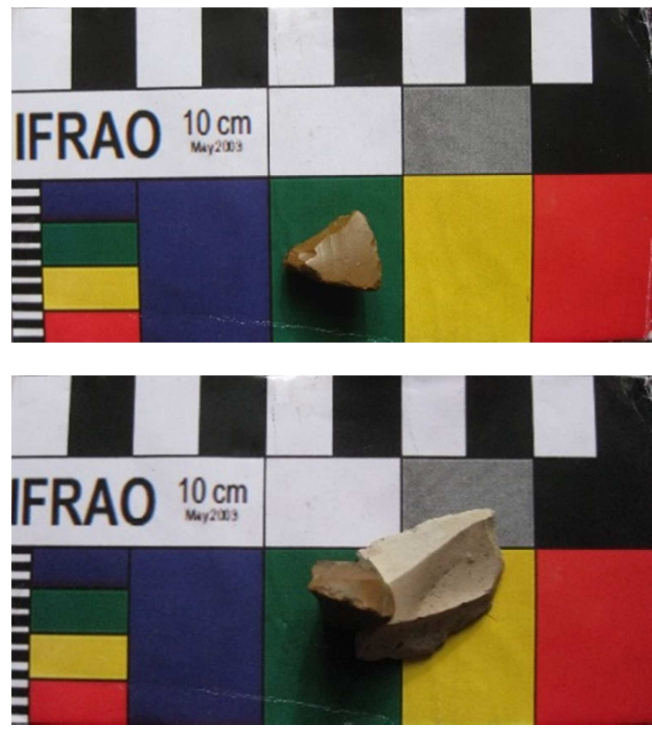

Fig. 5. Two hand axes or Levalloisian point are found in Chapaqan site [13]. 


\section{Dash Site}

This site is situated at point 1100 higher than sea level and respectively within latitude and longitude $\left(38^{\circ}, 33^{\prime}, 50^{\prime \prime}\right)$ and $\left(47^{\circ}, 51^{\prime}, 00^{\prime \prime}\right)$ among two villages of Dedebeyglu and Chapaqan. Most of designs are placed at eastern part of site. (Fig. 6).

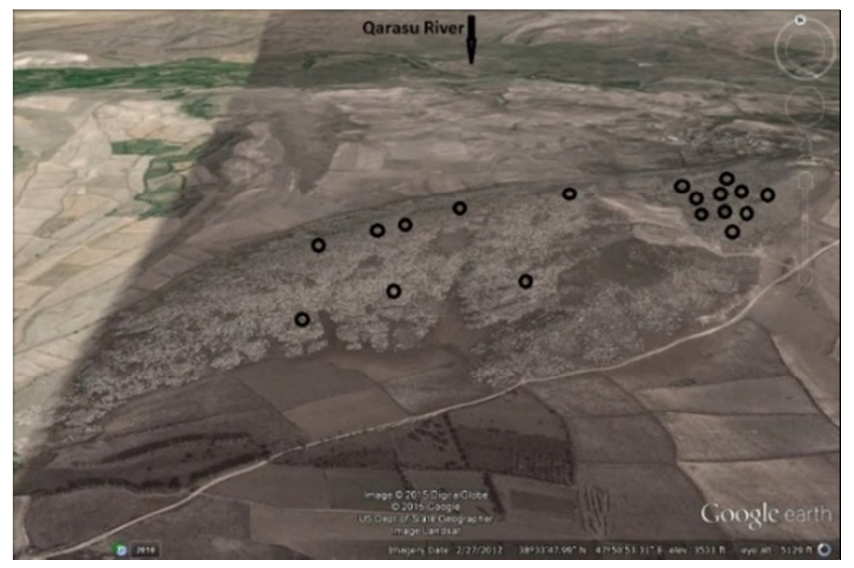

Fig. 6. Distribution of motifs in Dash complex beside the Qarasu River (Google Earth).

Another geometric motif is a stoked circular hollow. There is an Arc-shaped line that end of two sides leads down to a small circle (Fig. 7).

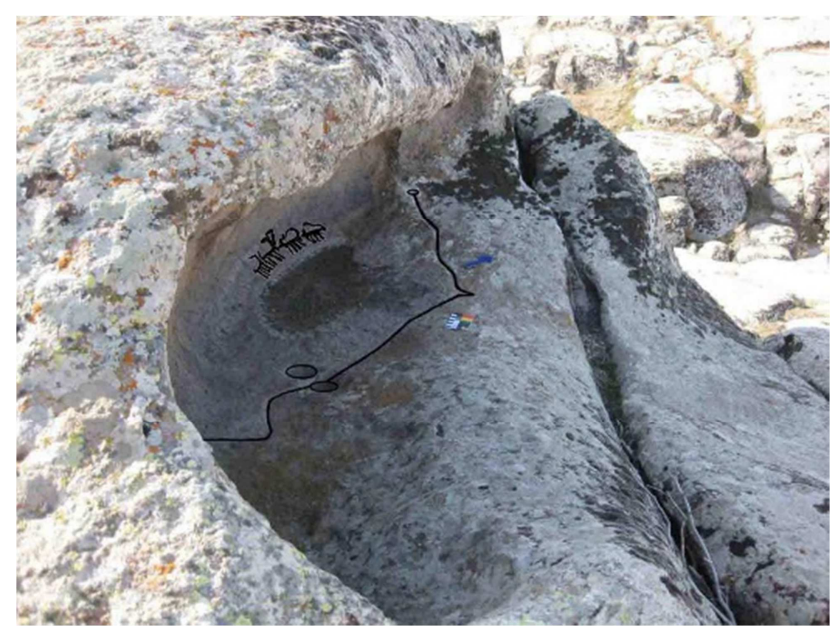

Fig. 7. Arc-Shaped Line in Dash [12].

Some samples of colorful paintings and designs have been found in caves and stony shelters at wide regions in north Asia, central Asia, and Iran where they have often drawn similar hunting scenes and different dates have been suggested for them.

\section{Qara Qaya Giller Mohammad Hassan Site}

This site is placed within latitude and longitude $\left(38^{\circ}, 26^{\prime}\right.$, $\left.44^{\prime \prime}\right)$ and $\left(47^{\circ}, 32^{\prime}, 40^{\prime \prime}\right)$ in $8 \mathrm{~km}$ distant from western area of Meshgin Shahr. Most of designs include animal designs (design of 8 antelopes in different sizes) and human moving designs. Picture of two goats on opposite side of each other has been drawn similar to design in Dash site and rock-pits can be observed similar to small rock-pits and groove in Dash site and Chapaqan here as well. Among inscribed designs in this region, there is groove-like design in Chapaqan and Dash on both ends of design a shallow pitlike point has been created where points have been initially created and then the related line has been drawn among two points. A design is also visible similar to this groove in Dash rock site but it is different from that design because design in Dash site is more complicated, disseminated, and with more depth. (Figs. 8 and 9)

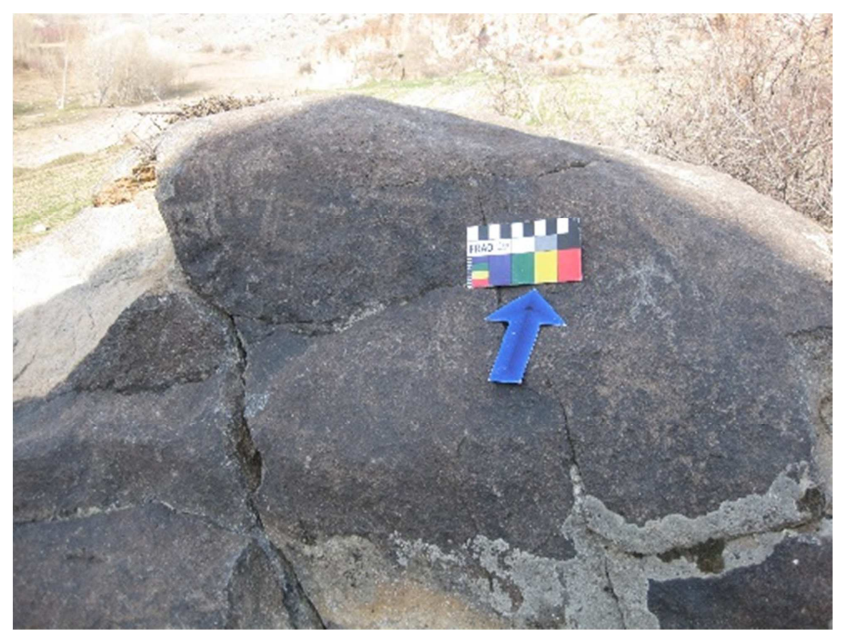

Fig. 8. Animal designs in Giller Mohammad Hassan site (Authors).

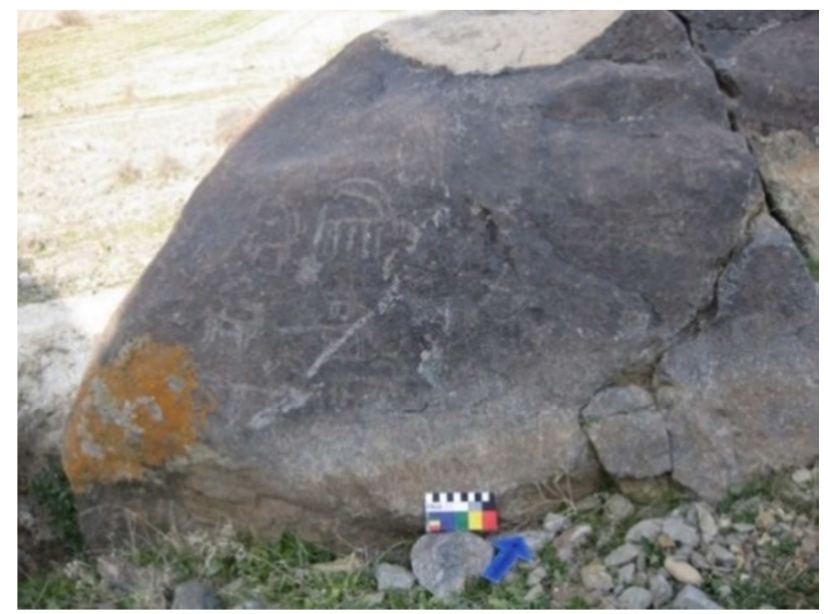

Fig. 9. Animal designs in Giller Mohammad Hassan site (Authors).

\section{Review of Rock Art Designs}

This point is clarified by observation and analysis on rock arts of Meshgin Shahr plain that all of engraved animals have been typically related to subject of sustenance, hunting, and human daily life. These designs can be divided in terms of frequency and quantity respectively as follows so we introduce some distinct samples of them: 1) antelope, 2) Deer, 3) Wild animals, and 4) Unknown. Animal designs are visible in general modes of motionless, walking, fighting 
against each other, and as a row of queue behind them.

Similar to Qarasu basin regions and other regions of Iran, most of these designs belong to picture of antelope that has been displayed as stylized and abnormal form. Sometimes, antelope designs are seen as animal flocks along with other animals. With respect to archeological findings, goat design has been almost constantly present in all of ancient centers. In fact, humans assumed goat as symbol of the useful factors in nature in prehistoric period [4]. Among paintings, there is picture of hoofed animals with slim body and drawn horns that seem to be deer. (Figs. 10 and 11)

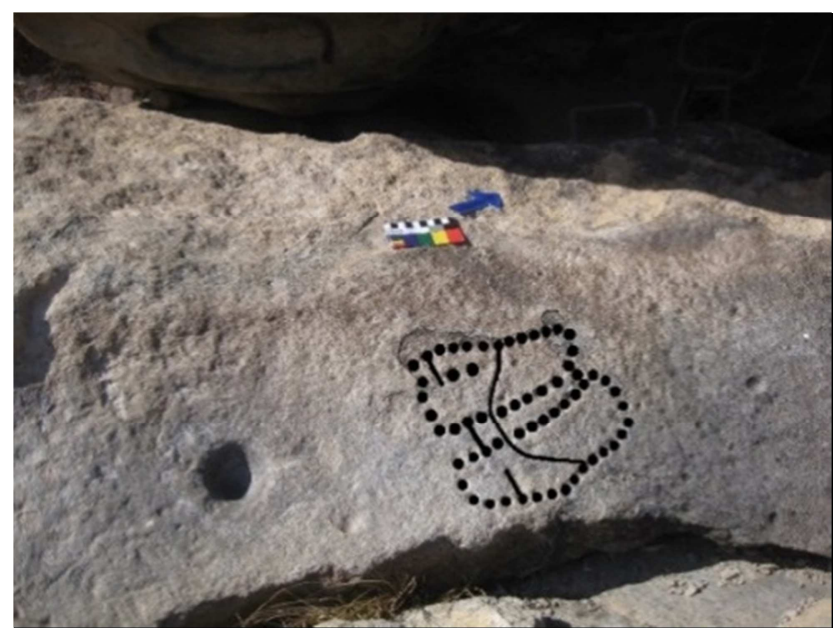

Fig. 10. One of the Cupule in Dash Complex [12].

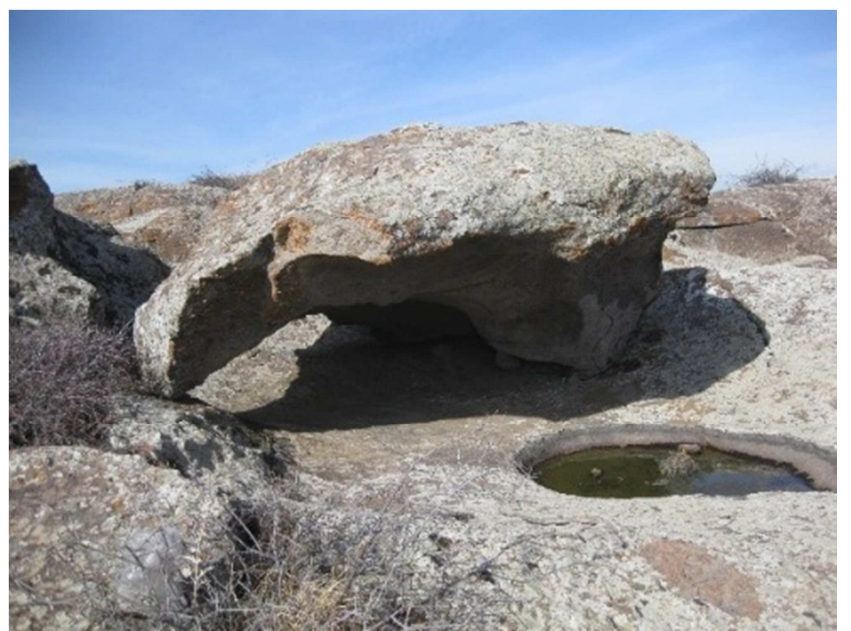

Fig. 11. Cupule in Dash Complex [12].

The rock pits to which maximum role is allocated, have been spread through the studied region. In addition to rock pits, some Cupule (sequin- like) designs are visible among them. Rather than Iran, rock pits have been also found in other sites e.g. world heritage of Qobustan, out of Böyükdaş, Kiçikdaş, and Cingirdağ. Researchers have supposed function of these pits for collection of rainwater, as vessels for cooking of cuisines, a place for gathering blood of sacrificed subjects, a plate for dying, and also celestial symbols [6]. The ethnographic data from various parts of world indicate that such pits have been also utilized in coking foods rather than collection of rainwater and blood of sacrificed subject in ritual- formality ceremonies. Custom of cooking watery foods in pits has been preserved by inhabitants of our region and transferred to us. For example, there is a custom for cooking of milk that is called Suqaç and Qoqurtmaç by the aid of hot rubbles thrown into pits that are done today in Azerbaijan Larik area in Zuvand as well.

\section{Conclusion}

Unfortunately due to absence of accurate calendar studies on Rock Art in Iran, we have not so far found any exact date for each of Rock Art and comparison of studied site with other dated sites in this region and even in world is the only factor that contributes us in conducting researches of this science. Presence of several colorful paintings is the first point about Dash site. Although it is a difficult task to determine date (year) of colorful painting art or pictography, with respect to other findings from other points of world, one can achieve relative dating scale. By analysis of the given techniques in Australia that is assumed as a rich land for this ancient art and the existing pigments in them, they have been dated back to Pleistocene epoch [5] and also by execution of accurate dating process at north Australia, pictography art has been dated back to 25000 years ago [22]. It seems that rock shelter had been created at the southern part of this region in Paleolithic age. One of the other cases that can be implied is the presence of various human and animal motifs so that by comparing Qobustan motifs [6], Gemi Qaya [1] and presence of animals e.g. goat and deer, Bronze Age may be supposed as the most probable date for drawing these samples. Lack of precise chronological data is a major obstacle for rock art researchers. They, therefore, have turned their attention to the relative dating. Cupules and two samples of flakes are the best available materials for dating the site. Numerous cupules, several rock shelters and even two flakes of Paleolithic periods are strong evidences of existing settlements in this region. It is very likely that this site is contemporary with Dash complex which is only two kilometers far from Chapaqan site. Another solution for dating this site is to compare the findings of this site with the rock arts and petroglyphs in Qobustan and Gami-Qaya. Another point to add is that, we believe, the depiction of these motifs is related to the dominant cultural criteria of that time. Other point we have found which can be related to the chronology of mentioned site are two hand axes or Levalloisian point.

The studied Rock Art designs within the region of study in Meshgin Shahr plain (Pirazmiyan, Nuqdu, Chapaqan, Dash, Dedebeyglu village, Giller Mohammad Hassan) include three groups of rock art, pictograph, and even rock pits with animal, human, geometric, and symbolic designs. North West of Iran was one of the most susceptible geographic locations for inhabitance and living of prehistoric humans up to present time where rock arts in Meshgin Shahr (Qarasu region) are evidences for this claim. According to number of engraved designs, Pirazmiyan region is composed of the greatest 
number of rock paintings at southern site of Qarasu River but generally Shikh Medi region also enjoys more variety and extent at northern region. In addition to ancient hills, which have been identified at Qarasu River basin, some other sites have been created such as groups of rock Art designs on flat walls of rocks or on large rocks so that they are assumed especially important from archeological and cultural- artistic perspective and at the same time presence of numerous animals denotes environmental conditions in the studied region. Rock arts are placed in Meshgin Shahr plain and even ancient region of Shahr Yeri city on fertile river basin. Rock Art designs of this site on this plain include human, animal, geometric, and symbolic figures. Most of designs belong to animal designs but one can also observe other motifs along with animal designs. The pictures in North West region of Iran are very similar to pictures at north of Aras River, particularly Qobustan site in terms of theme and painting styles. Therefore, with respect to accurate dating of Qobustan site, one can attribute date from Neolithic era to recent time to Qarasu region by comparing designs in these two regions. With respect to the existing findings, Qarasu rock designs have rich background in terms of settlement and inhabitance of tribes in this region, which is related to communities and tribes that experienced gradual phases of life from roaming and hunting to animal-husbandry and settlement on the same region. Given the proposed evidences and conducted comparisons, it seems that the Rock Art designs are the relics remained from prehistoric era on Qarasu River region that has been continued in imitative form and with specific features up to this day as well.

\section{Acknowledgment}

We are great thankful to Mr. Hassan Alizadeh due to his sincerity help for find ancient Rock Art places in Qarasu basin.

\section{References}

[1] Baxşəliyev, Vəli. 2006, Azərbaycan Arxelogiyasi, Naxçıvan Dövlət Universitəsi, Bakı.

[2] Bakhturtash, Nosratollah, 1977, Sun chariot or solar coach, Tehran: Atayee Press Publication Institute.

[3] Baxşəliyev V. B. 2002, Gəmiqaya təsvirlərinin poetikası. Bakı: Elm.

[4] Baxşəliyev V. B. 2004, Naxçıvanın qədim tayfalarının mənəvi mədəniyyəti. Bak1: Elm.

[5] David, Bruno, Geneste, Jean-Michel, Fiona Petchey, JeanJacques Delannoy, Bryce Barker, Mark Eccleston, 2013, How old are Australia's pictographs? A review of rock art dating, Journal of Archaeological Science, Volume 40, Issue 1, Pages $3-10$.

[6] Ferecova, Məlahət, 2007, «Qobustan Çalaları», Azərbaycan Dövlat Neșriyyati, Bakı.
[7] Hurshid, Shaghayegh, 2007, Introducing Shahar Yeri Petroglyphs (Arjaq Castle), Ancient Studies Journal. 3.

[8] Izad panah H. 1969. Prehistoric paintings in caves of Lorestan. Iranian Archeology and Art Journal 4: 6-14 (in Persian).

[9] Karimi, F, 2012. Arasbaran Petroglyphs. M. A Dissertation of Art History, Islamic Azad University, Shabestar Branch, Eastern Azerbaijan.

[10] Kazemi, Mohammad, Mirzaei, Mohammad, Ataei, Reza, 2015, Məşiran Qaya Rəsimləri, NEWS, AMEA, N3.

[11] Kazempur. M, Eskandari. N, Shafizade A, 2011, The petroglyphs of Dowzdaghi, North Western Iran, Documenta Praehistorica XXXVIII, Pp 383-387.

[12] Mirzaei, Mohammad \& Ali Karimi Kiya \& Nasrin Alizadeh \& Siyavash Abdollahi \& Vahid Ebrahimi. 2016, Studying the Petroglyphs of Dash Ancient Complex; Meshgin Shahr, North West of Iran (Azerbaijan, International Journal of Archaeology; Vol 4 (No. 3): 26-30.

[13] Mirzaei, Mohammad \& Ali Karimi Kiya \& Nasrin Alizadeh \& Siyavash Abdollahi \& Vahid Ebrahimi. 2016, An Archaeological Study of Petroglyphs in Chapaqan, Meshgin Shahr, Azerbaijan,, International Journal of Archaeology; Vol 4 (No. 3): 31-35.

[14] Naseri Fard, Mohamad, 2007. Stone museums, rock arts (Iran's petroglyphs). Arak: Navay-e Danesh Publication.

[15] Nurullahi, Ali, and Sara Alilou, 2011, Shepherding in the North West: The petroglyphs of Gery Kouh (two horses) at the foot of Zanjan Mountain, The Culture of Zanjan Journal, The Culture and Islamic Guidance Organization, Issue no. 31-32, pp 73-103.

[16] Paşayev, Sədnik, 1985, Azərbaycan xalq əfsanələri, Yazç1: Bak1.

[17] Rafiefar, J, 2002, Arasbaran Petroglyphs (Sungun). Anthropology Journal. 1 (1). P 44-75.

[18] Rafiefar, J, 2005, Arasbaran Petroglyphs. Tehran: Anthropology Research Institute publication.

[19] Rafiefar, J, 2009, Rock Art in North Western Iran, Hurans (Laqlan) Petroglyphs. Archeology, Research Institute publication.

[20] Rüstəmov, Cəfərqulu, 1994, Qobustan Dünyas1, Azərbaycan dövlət nəşriyyatı, bakı.

[21] Sinay, Sue, Anne, 2001, «Rock Art Native American Indians Southern California», Manhattan Beach. California, USA.

[22] Tolstoy, Leo. 1977. What is Art? (Trans. Dehgan, K). Tehran: Amirkabir. (In Persian).

[23] Watchman, Alan, 1993, Evidence of a 25,000-year-old pictograph in Northern Australia, Geoarchaeology, Volume 8, Issue 6, pages 465-473.

[24] Погребова М. Н. 1977, Иран и Заkавkазье в раннем железном веke. Mockва: Hayka, 182 c. 